\title{
An ideal for leadership - Psalm 72: The (wise) king - Royal mediation of God's universal reign
}

D J Human

(University of Pretoria)

\begin{abstract}
An ideal for leadership - Psalm 72: The wise king - Royal mediation of God's universal reign.
\end{abstract}

Psalm 72 propounds illuminating theological perspectives on leadership. The central figure in the psalm is the king. Throughout the Ancient Near East the king played a distinctive role, not only in contemporary politics, but also in religious life. Despite several differences from the other nations, kingship in Israel was rooted in the worldview of the ancient East. Yahweh, like other gods, commissioned the king for his tasks. The wise king in Israel, who alludes in Psalm 72 to the figure of Solomon, is obliged to rule with justice in order to maintain peace and prosperity in society.

The psalm is a prayer to God on behalf of the king. A litany of wishes emphasises the close relationship between Yahweh and the king. Wise leadership of the king will lead to the well-being of society. Before this theological principle is applied to modern leadership, one has to discover aspects regarding the composition of the text, its date of origin and the text's growth. Similarities between the psalm and a NeoAssyrian coronation hymn (7th BC) also reveal striking evidence.

\section{INTRODUCTION}

The quality of leadership determines the well-being of and prosperity in society. The current reality of poverty, starvation and epidemics, abuse and exploitation of political and military power, mass manslaughter, and oppression, violation of human rights and always-existing regional conflicts or inter-continental wars are merely symptoms of imbalances in leadership. Selfish and power driven leaders in all spheres of life corrupt their environments and societies to the deepest roots of life. Names like Osama bin Laden, Milosovic, Ghaddafi, Mugabe, Stalin, Hitler, but also leaders of the apartheid-era in South Africa inherently reflect stories of unhappiness and broken worlds. The devaluation of human life resulted in death and devastation. Not only were people's lives shattered and extinguished under such rule, but a lack of just leadership has thrown a shadow over people's experience of God's presence and his universal 
reign. Absence of justice and peace in the world results in the eclipse of a socio-political and cosmic order and prosperity.

In the rehabilitation of disordered communities, the restitution of well instituted justice and compassion should be implemented concretely. In order to do this, leadership in all spheres of life should be subjected to reassessment. Africa, but especially South Africa needs reliable leadership to participate in sustainable world development. South Africa's leading role in Africa requires sober leaders. Corruption, biased rule, bribery and self-enriching schemes (the "sauce train") will only widen the pit of doom and destruction. For the wholeness of the people and the land of Africa the quality of leadership in South Africa has to be addressed.

Psalm 72 propounds illuminating theological perspectives on leadership, which could resolve hopeless life-situations and encourage people in hopeless contexts to discover new horizons of life.

\section{PSALM 72: THE KING - A LEADER WITH A SPECIAL COMMISSION}

\subsection{Introduction}

The central figure in Psalm 72 is the king. Therefore, the text belongs to a group of Psalms known as the royal psalms ${ }^{1}$. Not only reflections on the duties of the Israelite king are portrayed in the text, but also the consequences, which are evolving from his office, become evident. His ruling deeds exercise both an influence on his direct subjects, the Israelite people, and on universal territory ( $\mathrm{v}$ 8), including the foreign nations (vv 11, 17). The king's relationship with Yahweh allows him to fulfil an intermediary role between God and people, because of his divine commission. In Israel, the king was a leader with a special commission and responsibility.

A superficial reading of the text creates an utopian and exaggerated impression of the earthly king and his abilities. How could his reign be eternal, as long as the sun or the moon give light (v 5)? Will all the kings and nations on earth serve him (vv 11, 17)? No human king in Israel has ever attained these ideals. Therefore, the preference for the

1 Cf Pss 2; 18; 20; 21; 45; 89; 101; 110; 132; 144. Westermann (1977:190) is convinced that these psalms reflect in a certain sense the actualisation of history ("Vergegenwärtigung von Geschichte"). The form and style correspond with ancient near eastern royal inscriptions (Seybold 1996:277). Since it mirrors a court style (see Gressmann 1929:15-19; Van der Ploeg 1973:427; Van Uchelen 1977:227; Kraus 1978:658; Prinsloo 1999:550, footnote 15), it was probably composed by a court poet or cultic prophet for an official royal court event. 
messianic reading ${ }^{2}$ of Psalm 72 by Targum and Midrash traditions ${ }^{3}$ as well as the christological interpretations of patristic ${ }^{4}$, medieval and even modern psalm exegetes ${ }^{5}$ comes as no surprise. This way of exposing the text, though, needs careful and nuanced reflection after the rise of historical critical scholarship.

Several issues dominate the research history of the psalm. One of the core questions touches on the quest for its historical Sitz im Leben. In which historical context(s) did the psalm originate, and under what circumstances? Did later situation(s) play a role in the text's growth and Nachwirkung of the psalm in the Old Testament? Are we dealing with a real king in Israelite history, or is the description one of an ideal king? Also, the liturgical function (cultic Sitz im Leben) and cultic purpose of the psalm evoked debate. A fundamental problem in the exposition of the text is the translation of different speech patterns and verb forms found in the psalm. Should the indicatives be formulated in the present or future tense, and the jussive forms as wishes or promises (in the future tense)? A decision for the one over the other always has implications for the interpretation of the psalm. But it should not prevent us from attempting an analysis and translation. However, it is not the intention of this discussion to formulate answers to all these problems.

\subsection{Kingship in the Ancient Near East and Israel}

Kingship was not invented by the Israelites. Throughout the Ancient Near East the king played a distinctive role, not only in politics, but also in religious life (Schmidt 1996-1968:247-249). According to Ancient Near Eastern concepts, he was seen as the representative of the god(s). Although there were differences between the Egyptian, Mesopotamian and Israelite understandings of their king(s), he was generally seen as a kind of intermediary figure between the god and his people.

In Egypt, the king was responsible for creating order in life and for expelling chaos according to the $M a$ 'at principle. This fighting against chaos in nature and society was done in order to preserve the order set by the $\operatorname{god}(\mathrm{s})$ in the Urzeit. To maintain order in nature and in society

\footnotetext{
2 The messianic reading phrases the expectation of a kingdom, where salvation and peace govern the whole earth under the reign of the Messiah-king. This expectation is modeled after the divine promise to David (2 Sam 7) about an eternal kingdom through the house of David.

3 Cf Braude (1959:563); Wünsche (1967: 362); Zenger (1993:61-62) and Hossfeld \& Zenger (2000: 329).

${ }_{5}^{4}$ E g Origen and Jerome, cf Jüngling (1998:835).

Cf Valeton (1903:213); Buttenwieser (1938:781); Ridderbos (1958:227); Deissler (1979:277). Duhm (1922:274-5) regards only a part of the psalm (vv 5-11) as foretellings ("Weissagungen") about a future messianic king.
} 
was, therefore, a high priority for the king. In society, his office mainly included obligations at the cult as well as the maintenance of juridical justice among the people (Assmann 1970:48). He had to bring offerings to the gods in order to satisfy them and to establish their presence in the cult. In Egypt he also embodied the unity of god and man; he was regarded in his office as a god.

According to the Ancient Near Eastern worldview, the gods ordained kingship. A god chose the king and gave him mercy to reign ${ }^{6}$. By divine commission the king then became the representative of the god. This divine legitimisation was necessary so that the king could act on behalf of the god. There was a symbiotic relationship between the earthly and divine kings. The earthly king became the legislator/ lawmaker who promulgated laws for justice and righteousness in the socio-political spheres of life ${ }^{7}$.

In the royal theology of ancient Israel, the kingship was similarly rooted in the worldview of the Ancient Orient. Despite a negative attitude towards kingship through the presence of anti-monarchical tendencies (1 Sam 8-12) ${ }^{8}$, this office was, nevertheless, introduced. Yahweh commissioned the king for his tasks. This becomes indirectly evident in Psalm 72:1, where the supplicant requests God to authorise the king's reign by giving him divine laws: "O God, endow the king with your justice, and the son of the king with your righteousness".

But the relationship between God and king in Israel was, in some regards, different from that in other parts of the ancient Orient. Here the king was not regarded as a god. Yahweh himself was the legislator. He reigned through the office of the king. He Himself fulfilled functions, which were carried out by the other ancient Near Eastern kings. Therefore, Yahweh was the actual king ${ }^{9}$ and judge. The earthly king merely

\footnotetext{
${ }_{7}^{6}$ See also 1 Sam 10:24; 16:8ff. etc.

7 A typical example is found in the prologue of the codex Hammurabi where the god Marduk ordered the king to guide the land and his people. Hammurabi then made laws to maintain law and justice.

8 This theocratic ideal testifies to the fact that kingship was at odds with authentic Yahwism at a certain time period of the Israelite history. It might have been a reaction against the experiece of tyrant leadership. Outside 1 Sam 8-12 these antimonarchical sentiments are only visible in Judges 8-9, where Gideon also rejected the kingship. Launderville (2001:119-128) makes a comparison between Israelite and Mesopotamian parallels regarding this anti-monarchical ideology. Schmidt (1961:75) also discusses this reservation against earthly kingship in Israel.

9 How this concept of kingship became part of the Israelite faith, especially in the pre-exilic period, and how it was conferred as epithet on Yahweh is a long debated theme in Old Testament scholarship. All the differences and resemblances of kingship between the Old Testament, Ugaritic and Mesopotamian conceptions are not yet cleared (Janowski 1989:454). Schmidt (1961:72) is of the opinion that
} 
fulfilled the function of a mirror or instrument, thus mediating the radiation (Abglanz) of Yahweh.

Another difference between Egyptian and Israelite kingship needs to be given attention. The maintenance of law and order in the sociopolitical sphere of life (Egypt) was transmitted in Israel to the theopolitical sphere. What the king did in the Egyptian society, God did through his royal office in Israel. A shift from a model of representative theocracy in Egypt to a model of maintaining law and justice in the theopolitical sphere of life becomes evident where Israel is concerned ( $\mathrm{J}$ Assmann 1992:64) ${ }^{10}$.

\subsection{TEXT AND STRUCTURE OF PSALM 72}

\subsubsection{Text}

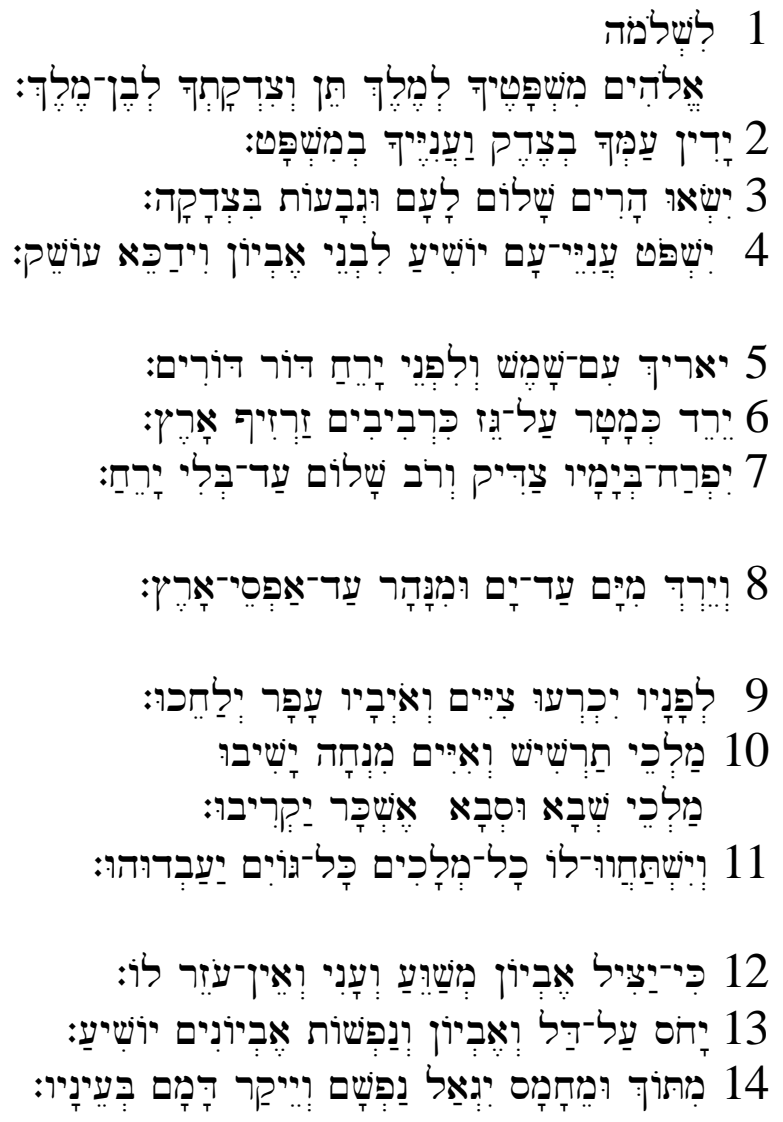

"Jahwes Königtum ist ein Erbe Kanaans", where his kingship developed from a mythological concept of Yahweh as king of the gods to Yahweh as king of Israel. Then he is simultaneously the lord of earth and of the nations. Jeremias (1987:1567) suggests the Autumn feast or Feast of the Booths as cultic "Haftpunkt" in Jerusalem for the Yahweh-king psalms.

10 This revolutionary concept in Israel is also called "identitäre Teokratie" (Assmann 1992:64). 


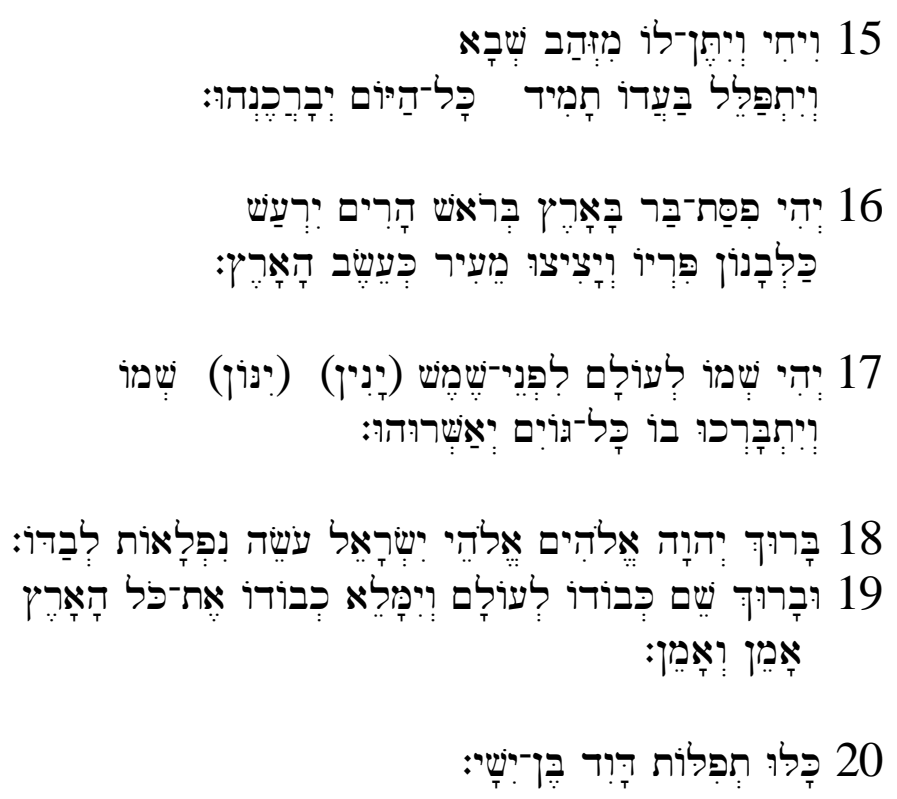

\subsubsection{Translation}

1a For Solomon.

1 O God, endow the king with your justice, and the son of the king with your righteousness (or: $\mathrm{O}$ God, give the king your laws and the son of the king your righteousness).

2 He will judge your people in righteousness, and your afflicted ones with justice.

3 The mountains will bring peace to the people, the hills the fruit of righteousness.

4 May he judge (do justice to) the afflicted among the people, (and) save the children of the needy; and may he crush the oppressor.

5 May he live long before the sun, and before the moon, from generation to generation.

6 May he be like rain falling on a mown field, like showers watering the earth.

7 In his days the righteous will flourish; and peace will abound till the moon is no more.

8 He will rule from sea to sea and from the River (Euphrates) to the ends of the earth.

9 Before him the inhabitants of the desert will bow and his enemies will lick the dust.

10 The kings of Tarshish and of the islands will come with presents; the kings of Sheba and Seba will approach with gifts.

11 All kings will bow down before him and all nations will serve him.

12 For he will deliver the needy who cry out, the afflicted who have no helper. 
13 He will take pity on the poor (weak) and the lives of the needy he will save.

14 From oppression and violence will he save their lives, for precious is their blood (lives) in his eyes.

15 May he live (long)! May gold from Sheba be given to him. May people ever pray for him and praise (bless) him all day long.

16 May abundance of grain be in the land; on the tops of the hills may it sway.

May its fruit flourish like the Lebanon; may they blossom from the city like the grass of the land.

17 May his name endure forever; as long as the sun, may his name be propagated.

All nations will be blessed through him, and they will call him happy (blessed).

18 Praise be to the LORD God, the God of Israel, who alone does marvellous deeds.

19 Praise be to his glorious name forever; may the whole earth be filled with his glory.

Amen and Amen.

20 The prayers of David son of Jesse ends (here).

\subsubsection{Textual observations}

The Hebrew text of Psalm 72 is transmitted in a well-preserved condition. Although this artistically composed psalm is not without textual problems, textual critical alternatives do not pose severe understanding problems for theological interpretations of the text. I suggest only one text critical emendation in verse 5 and propose replacing the Masoretic text (Mt) "may they fear you" (יריראיך) with the LXX reading, "may he live long"(יאריך). The MT in its current form, not only deviates from the third person singular imperfect form to the plural form in its context (vv 4, 6-8), but the second person suffix (as reference to Yahweh) in a royal song seems to be absent (Kraus 1978:656). However, this MT reading does not make good sense ${ }^{12}$ with the sudden change of subject, while the text emendation fits syntactically well into this literary context. The wish for the king to live long (v 5) also has a semantic parallel in verse 15, "may he live (long)", while the same verb form occurs in a description of the king's responsibilities in Deuteronomy

\footnotetext{
11 Numerous scholars accept this text alteration. Cf Duhm (1922:257); Gunkel (1926:309); Kittel (1929:238); Anderson (1972:521); Kraus (1978:656); Tate (1990: 119-120); Hossfeld \& Zenger (2000:305; 2002:415); Gerstenberger (2001:65).

2 Nowhere the king is addressed in the psalm; the antecedent of the plural form is not clear; the sudden change of subject to the plural form also implies a change of focus at this point in the text (Tate 1990:220).
} 
17:20. Verses $15-17$ serves as a parallel to 5-7 regarding to the cosmic dimension of the king's reign.

Psalm 72 contains a vast number of stylistic features. Despite concentric patterns in its micro and macro structures, the text reflects style figures like repetition (mišpat vv 1,2,4; am 2,3,4; erets vv 6,8,19; šemeš v 5,17 etc.), ellipsis (vv 2,3,6,7), contrast (v 4), pars pro toto or synecdoche (v 3), chiasm (vv 9, 11, 15b), rhyme (vv 9-11), merismus (vv 9 - 10), hyperbole (v 5), comparison ( $\mathrm{v} 16$ ) and others ${ }^{13}$. The function of each of these style figures contributes in every literary context to either the aesthetic or theological value of the text.

The text as a whole (vv 1-20) is characterised by both continuity (Einheitlichkeit) and discontinuity (Uneinheitlichkeit). Not only the heading (v 1a: "For Solomon"), the epilogue (vv 18-19: "Praise be... Amen and amen") and the colophon (v 20: "The prayers of David, son of Jesse, ends here") are later additions to the original psalm, but also verses $8-11,15$ and $17 \mathrm{~cd}$ can be motivated as secondary additions dating to later historical contexts ${ }^{14}$. This means that the exegete may reconstruct several Sitz(e) im Leben and Sitz(e) in der Literatur, which could serve as points of departure for the psalm's interpretation. Every stage of the text's growth in the history of Israel or in the book of Psalms and in the Tenach constitutes a new theological angle or meaning for the text. The redactional growth, composition and integration of Psalm 72 in the Tenach even allow for opportunities to interpret the text holistically or canonically as a messianic reading (Zenger 1993:65-72). A unilateral meaning of the text is, therefore, with these historical critical perspectives transcended.

\subsubsection{Structure}

Several structures ${ }^{15}$ have been proposed by exegetes to divide Psalm 72 into strophes or sub-divisions. These divisions are characterised by both concentric (Hossfeld \& Zenger 2000:311; 2002:412-412) and linear (Kidner 1973:254f; Gerstenberger 2001:64) patterns. For the purpose of this discussion, I divide the text, for morphological, syntactical, stylistic and semantic reasons, into the following units:

$\begin{array}{ll}\text { 1a } & \text { Heading } \\ \text { 1b-4 } & \text { Programmatic prologue }\end{array}$

13 Cf Van der Lugt (1980:309-310) for an overview on these features. Prinsloo (1999:536-554) also presents a thorough text-immanent analysis of Psalm 72, in which several style figures are identified.

14 See Hossfeld \& Zenger (2002: 413) for the motivation of these secondary additions.

${ }^{15}$ See Van der Lugt (1980:311) for an overview on suggested structures till 1980. 


\begin{tabular}{|c|c|}
\hline $1 \mathrm{~b}$ & Address to God \\
\hline $2-4$ & Justice to the poor \\
\hline $5-7$ & Blessing: enduring dominion and fertility \\
\hline (8)-11 & Universal reign of the king \\
\hline $12-14$ & Deliverance of the poor \\
\hline $15-17$ & Blessing: enduring dominion and fertility \\
\hline $18-19$ & Epilogue: doxology \\
\hline 20 & Colophon \\
\hline
\end{tabular}

Psalm 72 is a prayer ${ }^{16}$ to God on behalf of the Israelite king. The address to Elohim $(1 \mathrm{~b}-2)$ and the supplicant's litany of wishes ( $\mathrm{vv} 411 ; 15-17)^{17}$ testify to the close relationship between Yahweh and the king. The portrayal of the king in the first stage of Psalm 72 reflects the image of the divine king, Yahweh, behind this royal figure. As receiver of God's justice and righteousness ( $\mathrm{v}$ 1) the king is, due to his divine commission, a medium or agent, concretising and actualising God's given justice. As a subordinate he is dependent on God for this instrumental function. Stable and everlasting divine guidance of the king (v 5) therefore forms a basis for Israelite kingship. The king behind the king is the actual power on the throne.

Apart from the heading (1a), colophon (20) and doxologies (1819), the psalm consists of five parts: 1 b-4, 5-7, 8-11, 12-14 and 15-17.

Verses $1 b-4$ is a programmatic prologue, which starts initially with an intercessory prayer to God (1b), followed with a picture of the social dimension of the king's reign (2-4). He has the obligation to do justice to the poor in society. In 5-7 the blessed consequences of social justice are described in cosmic terms. In blending a picture of society and nature, the king becomes a personified life principle. Enduring dominion and abundance give description to the resulting wholeness (peace/prosperity) that could be experienced. Pictures of fertility in the land visualise this blessed outcome.

The central part, verses 8-11, depicts the universal dominion, which emanates from the king's just reign. The entire world becomes involved in this universal rule. The wholeness as consequence of the king's reign finds description in spacial terms and merismi, when all the kings and foreign nations come from "the ends of the earth" (8) to serve

16 Cf Gunkel (1926:305); Westermann (1980:107) calls it "totally an intercessory petition".

These wishes and blessings for the king, according to Van Seters (1992:287), serve as royal prototypes for the patriarchal blessings like those found in Gen 27:2829. Similar elements in both contexts are motives like the prosperity and fertility, superiority over other nations and enemies, as well as the expressions of blessing for the king. 
him. In view of Zachariah 9:9ff, the king and the personae miserae overlap in their poorness or humbleness. But the king, as oni (poor) and $\check{s}$ adiq (righteous) in Zechariah 9, comes as a universal king to bring salom (peace), like the just king in Psalm 72. Our psalm, therefore, not only makes reference to a real historical king (vv 1b-7; 12-14;16-17ab), but it opens a future horizon to profile aspects of the ideal king's reign (vv 8-11).

In verses $12-14$, like in 2-4, the social dimension of the king's just rule is described. There is an accumulation of semantic variants for "the poor" and the kings redeeming deeds. With compassion the king provides juridical help and deliverance to the poor, the afflicted and the oppressed. He saves them from oppression and violence.

In the last section, $15-17$, it is evident that the king's mediatory role of radiating divine justice results in enduring dominion and abundance. Wholeness in the land is realised through the king's mediation of God's dominion. The king's people and all the nations are expected to receive blessings in plenitude. Cosmic language depicts the fertility in nature, while the everlasting royal name advocates wealth and happiness. The jussive forms emphasise, in the last instance, that these blessings are given by Yahweh.

Allusions in $17 \mathrm{~b}$ to motives and language of Genesis 12:1-3, where God has promised Abraham the blessing of a land and an everlasting name, are no coincidence. Like Abraham, who functioned as mediator of God's blessing, the king has to fulfil the same role. The king's office is the continuation of Yahweh's engagement and blessed accompaniment in the history of Israel, which he started with Abraham. His mediation of justice and righteousness makes him the medium of God's blessing to his people, including the nations and kings of the universe. He thus becomes the realisation of God's promise to Abraham.

Hossfeld \& Zenger (1993:66; 2002:412 correctly identify an analogous pattern between 2-4 (social justice -A) and 5-7 (cosmos/ fertility in nature -B) and 12-14 (social justice -A') with 15-17 (cosmos/fertility in nature -B'). This parallel structure, not only builds a concentric pattern (A-B-C-A'-B') emphasising the universal and cosmic reign of the Yahwistic kingship (8-11), but there is also an intensifying Steigerung on a linear level from 2-7 to 12-17. Such intensification emphasises the blessing of abundance and fertility of life climactically.

\subsubsection{Heading (1a) and colophon (20)}

The heading לשימלמה (1a) raises the question of the psalm's authorship and dating. Although there are exegetes who ascribe its authorship to Solomon (Kirkpatrick 1957:416; Kidner 1973:254) or to the time of Solomon's enthronement (Ridderbos 1958:230), this possibility is by no 
means tenable. If Solomon was the author, the relationship between verses 1a and 20 ("The prayers of David, son of Jesse, end here") shows a severe contradiction. There are several correspondences between the figure of Solomon or the Salomonic history and Psalm $72^{18}$. However, in the history of Israel, Solomon was seen as one of the most prosperous and ideal figures, whose name was inserted as superscript by a later redactor. Allusions to him in the heading or in the text, which were brought about by redactional processes, recall the reign and kingdom of a wise ruler in Israel (1 Ki 3).

The redactional links between the corner psalms of the second Davidic collection (Pss 51 and 72), as well as the fact that Psalm 72 is the conclusive psalm in the small collection of Davidic psalms (69-72), may, in view of the colophon ("...prayers of David..."), lead to the assumption that the text was projected back into the history of Israel by the tradition as an intercessory prayer of the old and sick king David for his son Solomon ${ }^{19}$. Therefore, a better description of the heading would rather be "for Solomon". The character of the psalm as intercessory prayer is emphasised further when the supplicant requires justice from God, so that the Israelite king may concretise this God given justice for the poor and afflicted. Through this prayer, the supplicant also recognises the universal Yahwistic dominion. The colophon in 20 is unique in the book of Psalms. It serves as a connection between Psalm 72 and the second Davidic collection (Pss 51-72) or even as a conclusion of both Davidic collections (2-72)

\subsubsection{Doxologies (18-19)}

Verses 18 to 19 contains two benedictions. A sudden change of subject between 17 and 18 from the king to Yahweh characterises this transition. Not the king, but Yahweh is the focal point of attention. A strong hymnic character accompanies this theocentric perspective. The function of these doxologies is to relate the deeds and everlasting name of the monarch (šem; l'o olam - 17/19) with the deeds and everlasting name of Yahweh. It illustrates Yahweh as the real and only power above the throne. Not only His relationship with the king, but also with all other powers is profiled. The Israelite king disappears in the background behind the God of Israel, who alone is the one who does marvellous

\footnotetext{
18 See verse 8 with $1 \mathrm{Ki} 4: 21,24$; v 10 with $1 \mathrm{Ki}$ 10:1,21; v 15 with $1 \mathrm{Ki}$ 10:22. Gerstenberger (2001:65) illustrates how Solomon was portrayed as a man of justice, peace and prosperity. Even the wordplay between the heading לשלׁים (1a) and (vv 3,7) alludes to the root šlm.

${ }^{19}$ Theodore of Mopsuestia, cf Jüngling (1998;835).

${ }^{20}$ Mays (1994:239) and Seybold (1996:279) rather opt for this second possibility.
} 
deeds $^{21}$ in society and in nature (cosmos). Therefore, the focus falls on Him in congregational or cultic praise ${ }^{22}$. Simultaneously, the doxologies function as liturgical marker in the text. The Amen clause confirms the liturgical function of the psalm and validates the universal kingship of Yahweh.

The appearance of similar doxologies at the end of every book in the five-part division of the Psalter (Pss 41:14; 89:54; 106:48) reflects on a redactional hand. The five-part division of the Psalter by such doxologies alludes to the Torah, which was, according to Deuteronomy 17:18ff, important for the Israelite king to internalise and to obey. For him the Torah was the life-giving source for his submissiveness to Yahweh in order to reign for many years (אריך- Dt 17:20). With reference to Psalm 72, the Torah, which is represented by the mišpatim $(1,2,4)$, forms the basis for the king's wise conduct.

\subsubsection{Date and origin}

Several suggestions to date Psalm 72 in various contexts have been made by exegetes. Attempts cover a wide range of possibilities, namely from a pre-exilic ${ }^{23}$ monarchical time period up to an exilic ${ }^{24}$ or even a late postexilic date like the Maccabean ${ }^{25}$ epoch. Among these suggestions, the king of Psalm 72 has directly been related to people like Solomon (Kirkpatrick 1957:416 and Kidner 1973:254; Ridderbos 1958:230), Josiah (Kittel 1922:240) and Hezekiah (Stuhlmüller 1993:319). Gressmann (1929:16ff, 19) was - in the beginning of the previous century - convinced of the psalm's origin in the Neo-Assyrian era.

From a literary critical analysis, it becomes clear that the text has a primary Grundschicht (1b-7; 12-14; 16-17ab) with secondary additions

21 See Ex 15:11; 74:12; 77:15; 86:10; 136:4 for the marvellous deeds of Yahweh in the history and creation, cf Crüsemann (1969:125).

At this point in the text the benedictions are purely liturgical. This hymnic and festive language "ist dem geschichlichen Geschehen ganz entnommen" (Westermann 1977:66).

${ }^{23}$ Cf H Schmidt (1934:137); Oesterley (1939:337); Ridderbos (1958:229); Dahood (1968:179); Anderson (1972:518); Kraus (1978:657).

24 Böhl \& Gemser (1968:121) choose for a date in the Babylonian exile, when the Israelite people hope for the restoration of their late kingdom under a davidic ruler like Solomon.

${ }^{25}$ Cf Haupt (1909:286) speaks of a "ptolemäischen Psalm”, while Duhm (1922:278) speaks of a composition under Hasmonian rule. See also Briggs \& Briggs (1925: 132). Gerstenberger (2001:67-68) mentions several possible arguments for considering the psalm as a late post-exilic messianic poem (Aramaic influences; successive growth; Jewish community structures/theologies; feasibility of royal figure; intercession for a Great Emperor -e g Ezr 6:10 and Ps 61:7ff. Van der Ploeg (1973:428) also regards the Aramaeisms as indication of the late dating of the psalm (vv 4, 5, 6, 16). 
(vv $8-11 ; 15 ; 17 \mathrm{~cd} ; 18-19 ; 20)$. While exegetes mostly date the basic psalm as pre-exilic, the secondary additions are dated to an exilic/postexilic period. In the different phases of literary growth, including redactional revision and canonical processes, the psalm assumes a new shape in its new (later) context(s). One, therefore, could reckon with a deviation from prior form and meaning as well as with the addition of theological perspectives. This state of affairs anticipates several Sitze im Leben behind Psalm 72, which are either historical, cultic or literary.

Although the reconstruction of any psalm's origin is hypothetical, it remains the obligation of the exegete to reconstruct possible diachronic contexts in which the text could be understood. The contribution of two exegetes deserves attention in this regard, namely that of Erich Zenger and Martin Arneth.

Zenger (Hossfeld \& Zenger 2002:413) explains the growth of Psalm 72 in two phases. He identifies a Primärfassung $(1 \mathrm{~b}-7$; 12-14; 16$17 \mathrm{~b}$ ) in the $7^{\text {th }}$ century BCE, which was influenced by Ancient Near Eastern and Egyptian conceptions of kingship. This layer also presupposes anti-Assyrian tendencies, prophetic-social criticism of the $8^{\text {th }}$ century, BCE as well as the theologising of the transmitted legal collections. In its basic form it is a theological, programmatic text of Israel's royal theology, which has its Sitz in der Liturgie. According to Zenger, this Fassung was added intentionally as a final psalm to the second davidic Psalter, 51-72, by its redaction/redactors.

A further single Bearbeitung of the text was the addition of verses $8-11,15$, and $17 \mathrm{bc}$ to the original psalm in approximately $300 \mathrm{BCE}$. Bearbeiter, who established the so-called Messianic Psalter, 2-89, has added these verses to the already existing text. With Psalm 2:1-9 as introduction to this redactional group of psalms, the so-called Völkerthema was given special emphasis within the royal theology. The hands of this redaction were also responsible for the doxology (18-19) and heading (1a) of the psalm.

Arneth $^{26}$, who argues in similar fashion to Zenger, provides an interesting and creative thesis on the origin and development of Psalm 72. In his attempt to explain "the solarising" of the Yahweh faith in Israel, he describes the origin of Psalm 72 as a direct result of Assur's presence in Palestine and Judah during the $8 / 7$ centuries BC. The text must have originated shortly after the enthronement of Assurbanipal in 669 BC. In allusion to the middle-Assyrian royal rituals, a coronation hymn, which served as legitimisation for the king's reign, was dedicated to Assurbanipal. This hymn must have served as Vorlage for the origination of our discussed psalm.

${ }^{26}$ Arneth (2000:201-208) gives a summary of the results of his dissertation. 


\section{ASSURBANIPAL'S CORONATION HYMN}

English translation $^{27}$

(1) May Shamash, king of heaven and earth, raise you to shepherdship over the four regions!

May Assur, who gave you the [scepter], prolong your days and years!

Spread your land wide at your feet!

May Sherua extol your name to your personal god!

(5) Just as grain and silver, oil, the cattle of Shakan and the salt of Bariku are good, so may Assurbanipal be favored by the gods of his land!

May eloquence, understanding, truth and justice be granted him as a gift!

(9) May the [population] of Assur buy thirty kor of grain for one shekel of siler! May the [population] of Assur buy three seah of oil for one shekel of silver! May the [population] of Assur buy thirty minas of wool for one shekel of silver!

(12) May the lesser speak and the [greater] listen! May the greater speak and the [lesser] listen! May concord and peace be established in Assyria!

(15) Assur is king - indeed Assur is king! Assurbanipal is the [representative] of Assur, the creation of his hands!

May the great gods make his reign firmly established! May they guard the life of Assurbanipal, king of Assyria!

May they give him a straight scepter to widen his land and peoples!

May his reign be renewed and may they firmly establish his royal throne for ever!
German translation $^{28}$

"Möge Samas, der König von Himmel und Erde, dich in das Hirtenamt über die ganze Welt einsetzen!

Möge Assur, der dir das Zepter übergab, deine Tage und Jahre lang machen!

Mache das Land weit unter deinen Füssen!

Möge Seru'a deinen Namen vor deinem Gott lobend erwähnen!

Genauso gut wie Getreide und Silber, Öl, die Rinder des Sakkan und das Salz von Bariku gut sind, so möge Assurbanipal, der König von Assyrien, auf Wohlwollen der Götter dieses Landes treffen!

Mögen Beredsamkeit, Verständnis, Rechtssinn und Gerechtigkeit ihm als Gaben geschenkt sein!

Mögen die Bürger von Assur 30 Kor Getreide für einen Schekel Silber, mögen die Bürger von Assur 3 Seah Öl für einen Schekel Silber kaufen! Mögen die Bürger von Assur 30 Minen Wolle für einen Schekel Silber kaufen!

Möge der Geringere sprechen und der Mächtigere zuhören! Möge der Mächtigere sprechen und der Geringere zuhören! Mögen Eintracht und Frieden in Assyrien aufgerichtet werden!

Assur ist König - wahrhaftig Assur ist König, Assurbanipal ist der [Repräsentant] Assurs, Geschöpf seiner Hand.

Mögen die grossen Götter seine Regierung befestigen, mögen sie das Leben Assurbanipals, des Königs von Assyrien schützen!

Mögen sie ihm ein mächtiges Zepter geben, um seine Herrschaft über Land und Völker auszudehnen.

Möge seine Königsherrschaft erneuert werden, und mögen sie seinen Königs-

\footnotetext{
${ }^{27}$ Cf Hallo \& Younger (1997:473-474) for the translation of A Livingstone.

${ }^{28}$ Cf Otto (1999:22-23; 2001:44-45).
} 
Daily, monthly and yearly may they bless him and guard his reign!

(20) During his years may rains from heaven and floods from the underground source be steady!

Give our lord, Assurbanipal, long [days], copious years, great strength, a long reign, years of abundance, good repute and fame, health and well-being, a propitious oracle and leadership over other kings! thron auf ewig befestigen!

Mögen sie ihn segnen, tagelang, monatelang, jahrelang und seine Königsherrschaft beschützen!

Möge ständig während seiner Regierungsjahre Regen vom Himmel fallen und Flut aus den Quellen aufsteigen!

Gib unserem Herrn Assurbanipal lange, reiche Jahre, starke Waffen, eine lange Königsherrschaft, Jahre des Überflusses, einen guten Namen, Ruhm, Glück und Freude, günstige Omen und Herrschaft über (alle) Könige."

Arneth, like Zenger, identifies a basic psalm (1b;2-7; 12-14; 16; 17aaß), which has undergone two redactional processes. Verses 1 (heading) and $18 \mathrm{ff}$ belong to a last redaction or Bearbeitung of the text, while a first revision $(8-11 ; 15 ; 17 \mathrm{a}$ ?b) was probably done in the exilic and early post-exilic period through the insertion of motives regarding the universal reign of the king.

The basic psalm emerges in direct dependence on the coronation hymn of Assurbanipal and has a "literarische Vorbildfunktion" for Psalm 72 not without motivation. Structural composition (especially 72:3-7 with the hymn 8-14), similar Stichworte (sedaqah and šalom) and themes like "law and justice", "enduring domination" and "fertility" resemble the correspondences between these texts. From here on, Arneth (2000: 204) depicts the poem as a coronation hymn ${ }^{29}$ of king Josiah $(639 \mathrm{BC})^{30}$, whose reign was accompanied by anti-Assyrian tendencies. These tendencies behind the text were due to the foreign politics of the Assyrians. Concrete experiences like the fall of the Northern Kingdom, deportations under Salmaneser V and Sargon II, the siege and conquest of Lachish, as well as the deportations of Sennacherib all constitute the situation of deprivation in the afflicted Israelite community, caused by the Assyrians.

Soteriological elements in the Assurbanipal hymn are transferred to the relationship between Yahweh and the Judean king. Assur disap-

29 This suggestion coincides with research results where the cultic Sitz of the psalm could be a inauguration or coronation ceremony of the king - in Jerusalem- (Gunkel 1926:305; Oesterley 1939:339; Tate 1990:222; Mays 1994:236) or an annual celebration of the king's enthronement at a harvest feast or on a New Year festival (Anderson 1972:518; Kraus 1978:658). For Mowinckel (1961:93,96) both these possibilities should be taken into consideration.

30 Arneth (2000:204) motivates this example function of Josiah with the independent texts of Is 9:1-6 and Jer 22:15-17. 
peared from the text of Psalm 72 while allusions to Shamash $(5,17)$, the sun god and guarantor of law and justice, still prevail. Despite these allusions, Yahweh has replaced this classical function of Shamash as ordainer and guarantor of law and order. Consequently, Yahweh is solarised. It is therefore evident that Psalm 72 presupposes polemic tendencies between Yahweh and the Mesopotamian gods, Assur and Shamash, simultaneously. Ideologically the psalm not only denies, but also combats new Assyrian claims to rule in Judah.

In the psalm it becomes clear that not only the supplicant who prays (1), or the king (1, 18-19), and Gods poor and afflicted people (2), yes, even all the kings and the nations (11), but the whole earth (19), are subordinate to God, who alone deserves praise for his marvellous deeds. Even the solar and astral elements, namely the sun $(5,17)$ and the moon $(5,7)$ are merely stable heavenly bodies that serve as measuring instruments for the king's life.

To understand Psalm 72 as a coronation hymn of Josiah against the background of anti-Assyrian tendencies, offers - in my opinion - an appealing suggestion for a possible historical Sitz im Leben of the first Fassung of the psalm (1b;2-7; 12-14; 16-17aaß). The oppression, deprivation and poverty caused by the Assyrian foreign policies in the Israelite community fulfil an exemplary Sitz im Leben of the psalm. Later additions to the text about the universal dimensions and implications of the king's rule were, due to pentateuchal and prophetical allusions in $8-11 ; 15 ; 17 \mathrm{~b} ; 18-20$, rather later post-exilic than early postexilic. Besides their theological meaning in the psalm as a whole, the doxologies and colophon also serve redaction historical purposes. The integration of the psalm through them in larger corpi or canonical units of the Psalter extends the semantic horizon of Psalm 72.

\section{AN APPLICATION FOR MODERN LEADERSHIP}

Psalm 72 unmistakably recounts the wise conduct of just ruling, and the consequent social and cosmic well-being and peace (prosperity) that emanates from it for society. Not only for the poor and needy among God's people does it offer wholeness, but theologically it widens the perspective of Yahweh as God of Israel (18) to a universal perspective of him as the One who does marvellous deeds on the whole earth (19). Being a reflection of divine justice ("een afspiegeling van het goddelijke recht" cf Noordtzij 1935:10) the earthly king mediates God's universal reign.

In similar fashion to the office of the king in ancient Israel, leadership in the modern world and especially in Africa should be responsible for the ordering of social and cosmic disorder, which manifests in situations. These problems were thoroughly discussed at the World Summit 
for Sustainable Development ${ }^{31}$. Human and cosmic structures that are threatened by internal and external dangers are dependent on the guidance of leaders that are reliable and trustworthy. The constant disposal of chaos belongs to the daily obligation of leadership.

Modern leaders should orientate themselves towards the basic function of leadership, namely to establish justice and peace - ̌̌edakah and šalom - in their societies. Core objects of their enterprise should be the poor, the oppressed and the afflicted - figures and groups on the periphery of society; people who find themselves in marginalised and distressful social circumstances.

More important, though, is the concretising and realisation of these principles for the applicable objects ( $\mathrm{vv} 4,12-14)$. The upliftment of poverty $(2,4)$, needs $(12-13)$, oppression $(4,15 b)$ and violence (v $15 \mathrm{~b}$ ) must receive attention on the agendas of leaders in all sectors and levels of society. The people in a democratic society should reject vehemently unfulfilled political promises

Leaders should constantly be made aware of the social and cosmic implications of their leadership as well as the interrelatedness between these two dimensions. Rule by just reign results in the well-being of a society. Such leaders are personified life-giving principles. In the metaphors of Psalm 72, they are like "rain falling on mown grass" (6), like "showers watering the earth (6) and the fruit of their reign is "like the Libanon" (16). A lack of this conduct of Gerechtichkeit ends up in devastation and destruction of society and cosmos.

In a society like South Africa, where almost 79 percent $^{32}$ of the population has indicated their religious affiliation, it should be noticed that the reverence of a deity is related to peoples' social deeds and decisions. Unjust or reluctant rule of any believing leader does not only reflect on his/her own name (reputation), but it has an influence on how his/her deity will be viewed by other people in society. Theologically spoken, reluctant and unjust rule of any believing leader will dishonour his/her own god. Like the Israelite king, the believing leader is an extension (instrument) of his god's work in creation and society.

Psalm 72, a royal psalm, and prayer that portrays the role and duties of the Israelite king, poses challenges to modern leadership. In Africa, and particularly in South Africa, these challenges should be accepted and taken seriously. This prayer is an expression of trust in

\footnotetext{
31 This World Summit on Sustainable Development was held during August-September 2002 in Sandton, Johannesburg (South Africa).

32 Cf J J Kritzinger (2000:111-112) gives a summary on the religious denominations of the last South African sensus in 1996. 75,4 persent are Christians, while affiliates of all the other religions (including people who have indicated their affinity with no religion) constititute the rest.
} 
God, who is asked to grant the king justice and righteousness for his office. It recognises God as the actual leader and encourages the afflicted and poor that God will deliver them through an ideal leader. May the leaders of the World Summit fulfil their long debated promises and undertakings! Many of them have represented very poor and distressed people. May Africa, and in particular South Africa, transcend its brokenness and poverty by choosing and maintaining better leadership on all levels of church and society.

\section{Consulted literature}

Anderson, A A 1972. Psalms 1-72 (NCBC). London: Oliphants.

Arneth, M 2000. "Sonne der Gerechtigkeit". Studien zur Solarisierung der JahweReligion im Lichte von Psalm 72 (Beihefte zur Zeitschrift für Altorientalische und Biblische Rechtsgeschichte 1). Wiesbaden: Harrassowitz.

Assmann, J 1970. Der König als Sonnenpriester. Ein kosmographischer Begleittext zur kultischen Sonnenhymnik in thebanischen Tempeln und Gräbern (ADAI VII). Glückstadt.

-, 1992. Politische Teologie zwischen Ägypten und Israel. München.

Boadt, L \& Smith M S (eds) 2001, Imagery and imagination in biblical literature. Essays in honor of A Fitzgerald, F.S.C. (CBQ Monograph series 32). Washington: Catholic Biblical Association of America.

Böhl, F M T de Liagre \& Gemser B 1968. De Psalmen (Tekst en Uitleg). Nijkerk: Callenbach.

Braude, W G 1959. The Midrash on the Psalms translated from the Hebrew and Aramaic by W G Braude (Yale Judaica series XIII). New Haven: Yale University Press.

Briggs, C A \& Briggs E C 1925. The book of Psalms II (ICC). Edinburgh: T \& $\mathrm{T}$ Clark.

Buttenwieser, M 1938. The Psalms. Chicago: University of Chicago Press.

Crüsemann, F 1969. Studien zur Formgeschichte von Hymnus und Danklied in Israel (WMANT 32). Neukirchen-Vluyn: Neukirchener Verlag.

Dahood M 1968. Psalms II (51-100). A new translation with introduction and commentary (AB series 17). New York: Doubleday.

Deissler, A 1979. Die Psalmen. 2. Auflage. Düsseldorf: Patmos Verlag.

Duhm, B 1922. Die Psalmen (Kurzer Handkommentar zum Alten Testament XIV). Tübingen: Mohr (Siebeck).

Farmer, W R (ed) 1998 et all. The International Bible Commentary. A Catholic and Ecumenical Commentary for the Twenty First Century. Minnesota: Liturgical Press.

Gerstenberger, E 2001. Psalms, Part 2, and Lamentations (FOTL XV). Grand Rapids, Michigan: Eerdmans.

Gressmann, H 1929. Der Messias. Göttingen: Vandenhoeck \& Ruprecht.

Gunkel, H 1926. Die Psalmen - übersetzt und erklärt. Göttingen: Vandenhoeck \& Ruprecht.

Hallo, W W \& Younger K L (eds) 1997. The Context of Scripture. Volume I. Canonical compositions from the Biblical World. Leiden/New York/Köln: Brill. 
Haupt, P 1909. "Lea und Rachel”, Zeitschrift für die alttestamentliche Wissenschaft 29/4 (1909): 281-286.

Hossfeld, F-L \& Zenger, E 2000. Psalmen 51-100, übersetzt und ausgelegt (HThKAT). Freiburg/Basel/Wien: Herder.

-, 2002. Die Psalmen II (NEB Reihe). Würzburg: Echter.

Janowski, B 1989. "Das Königtum Gottes in den Psalmen. Bemerkungen zu einem neuen Gesamtentwurf', Zeitschrift für Theologie und Kirche 89 (1989): 389454.

Jeremias, J 1987. Das Königtum Gottes in den Psalmen. Israels Begegnung mit dem kanaanäischen Mythos in den Jahwe-König-Psalmen. Göttingen: Vandenhoeck \& Ruprecht.

Jüngling, H-W 1998. "Psalm 72", in Farmer, W $\mathrm{R}(\mathrm{Ed})$ et all. The International Bible Commentary. A Catholic and Ecumenical Commentary for the Twenty First Century. Minnesota: Liturgical Press.

Kidner, D 1973. Psalms 1-72 (Tyndale OT Series). London: Intervarsity Press.

Kirkpatrick, A F 1957. The Book of Psalms. 12 $2^{\text {th }}$ edition. Cambridge: Cambridge University Press.

Kittel, R 1929. Die Psalmen übersetzt und erklärt (KAT). Leipzig: DW Scholl.

Kraus, H-J 19785. Psalmen. 2.Teilband - Psalmen 60-150 (BKAT XV/2). Neukirchen -Vluyn: Neukirchener Verlag.

Kritzinger, J J 2000. "Mission in the new South Africa. Need for a renewed enquiry". Skrif en Kerk 21(1) (2000): 93-114.

Launderville, D 2001. "Anti-monarchical ideology in Israel in light of Mesopotamian parallels", in Boadt, L \& Smith M S (eds), Imagery and imagination in biblical literature. Essays in honor of A Fitzgerald, F.S.C. (CBQ Monograph series 32). Washington: Catholic Biblical Association of America.

Mays, J L 1994. Psalms (Interpretation series). Louisville, Kentucky: John Knox Press.

Mowinckel, S 1962. Psalmenstudien II (Buch III - Kultprophetie und prophetische Psalmen). Amsterdam: Schippers.

Noordtzij, A 1935. Psalmen (Korte Verklaring der Heilige Schrift). Kampen: Kok.

Oesterley, W O E 1939. The Psalms II. London: SPCK.

Otto, E 1999. Krieg und Frieden in der Hebräischen Bibel und im Alten Orient (Theologie und Frieden 18). Stuttgart/Berlin/Köln: Kohlhammer.

-, 2001. Die Tora des Mose. Die Geschichte der literarischen Vermittlung von Recht, Religion und Politik durch die Mosegestalt. Göttingen: Vandenhoeck \& Ruprecht.

Prinsloo, W S 1999. "Psalm 72: 'n Verskuiwing van die mistieke" na die politieke?" Old Testament Essays 12/3 (1999): 536 - 553.

Ridderbos, J 1958. De Psalmen vertaald en verklaard. Deel twee: Psalm 42-106 (COT). Kampen: Kok.

Seybold, K 1996. Die Psalmen (HAT I/15). Tübingen: Mohr (Siebeck).

Schmidt, H 1934. Die Psalmen (HAT). Tübingen: Mohr (Siebeck).

Schmidt, W H 1961. Königtum Gottes in Ugarit und Israel. Zur Herkunft der Königsprädikation Jahwes. Berlin: A Töpelmann.

33 The title of this article was added after the death of W S Prinsloo and should probably read "Psalm 72: "n Verskuiwing van die mitiese na die politieke?". 
-, 1996. Alttestamentlicher Glaube. 1968 - 8. vollständig überarbeitete und erweiterte Auflage. Neukirchen- Vluyn: Neukirchener Verlag.

Stuhlmüller, C 1993. Psalms I (Old Testament Message 21). Minnesota: Liturgical Press.

Tate, M 1990. Psalms 51-100 (WBC 20). Dallas, Texas: Word Books.

Valeton, J J P 1903. De Psalmen. Tweede Deel (Psalm XLII-LXXXIX). Nijmegen: $\mathrm{H}$ ten Hoet.

Van der Lugt, P 1980. Strofische structuren in de Bijbels-Hebreeuwse poëzie. Kampen: Kok.

Van der Ploeg, J P M 1973. Psalmen uit de grondtekst vertaald en uitgelegt (BOT). Roermond: JJ Romen en zonen.

Van Uchelen, N A 1977. Psalmen deel II (POT). Nijkerk: Callenbach.

Van Seters, J 1992. Prologue to History. The Yahwist as Historian in Genesis. Louisville (Kentucky): Westminster, John Knox Press.

Westermann, C 1977. Lob und Klage in den Psalmen. Göttingen: Vandenhoeck \& Ruprecht.

-, 1980. The Psalms. Structure, content and message. Minneapolis: Augsburg Publishing House.

Wünsche A, 1967. Midrasch Tehillim oder haggadische Erklärung der Psalmen. Hildesheim: G Olms.

Zenger, E 1993. So betete David für seinen Sohn Salomo und für den König Messias. Überlegungen zur holistischen und kanonischen Lektüre des 72. Psalms. Jahrbuch für Biblische Theologie 8 - Der Messias- (1993): 57-72. 